\title{
CXVIII. STUDIES ON INOSITOL.
}

\section{THE SYNTHESIS OF INOSITOL IN THE ANIMAL BODY.}

\author{
By JOSEPH NEEDHAM (Benn Levy Student). \\ From the Biochemical Laboratory, University of Cambridge.
}

(Received July 22nd, 1924.)

INOSITOL, the most important member of the cyclose group, once thought to be a carbohydrate, and now known to have the formula of hexahydroxycyclohexane, appears to be a constant constituent of all animal and vegetable cells. But in spite of its exceedingly wide distribution, and the considerable amount of work which has been carried out upon it, we are still ignorant of its functions and metabolic relationships. In approaching such a subject there would seem to be certain steps which must inevitably be taken before all else, and the first of these is the elaboration of a satisfactory method of estimation, while the second is to find out whether or not the animal body has the power of synthesising the substance. Such information is absolutely necessary for further experiment, and little can be done until it is gained. In the first of these papers $[1923,1]$ there was described a method of estimating inositol, which has an accuracy of $90 \%$ and which is capable of being employed upon as little as $12 \mathrm{~g}$. of tissue. The next step was to try to find out whether the animal body has the power of synthesising the inositol ring.

Previous workers, no doubt owing to the absence of a method of estimation, had made no attempts to attack the problem directly, but indications of various kinds were not wanting. Vohl [1858] had reported that from the urine of a case of diabetes insipidus he had succeeded in isolating from 18 to $20 \mathrm{~g}$. of inositol per diem. In view of the imperfect methods of isolation which were in use at that date, his data might seem doubtful, had not Hopkins [1923] found a very similar case, excreting about $15 \mathrm{~g}$. every day. Such quantities of inositol could certainly not be coming in in the food, especially as inositol is readily broken down by $B$. coli in the intestinal tract. No other conclusion is possible except that synthesis must have taken place. Offergeld [1906] could find no inositol in the blood of a pregnant woman, and as the tissues of young children are known to contain it, concluded that the foetus must be synthesising its own. Little importance can be attached to this observation as Offergeld only used a litre of blood, and blood only contains inositol in very low concentrations. The present writer was able to isolate $1 \cdot 1 \mathrm{mg}$. $\%$ from the blood of the goat. Klein [1909] was unable to isolate any inositol from the 
unincubated hen's egg, but found some present in the hatched chick and therefore concluded that a synthesis had taken place. These observations will be returned to later. Starkenstein [1909], in the course of a general investigation into the metabolism of inositol, starved rabbits for eleven days, and at the end found no diminution in the inositol-content of their muscles. His conclusion was that inositol was not broken down in the body, but the experiment is not conclusive, for it takes no account of the considerable amounts of combined inositol which exist in the body, and can as easily be explained by saying that what he was measuring was a condition of maintained equilibrium. This experiment is also no evidence that synthesis can take place for the same reasons.

It seemed clear that little help could be expected from the older literature. Apart from all other considerations, no worker had ever taken care to control the diet, and rats, animals which live well on a "pure" diet composed of pure carbohydrate, protein, and fat, had never been used as experimental material. The problem obviously needed a new line of approach.

At this point another series of papers seemed important in this connection. Diabetes insipidus, with its related condition, inosituria, is a pathological state which has been attracting the attention of clinicians for over a century. It was only distinguished in the early years of the nineteenth century from diabetes mellitus by the fact that there was no sugar in the urine, hence the name "zuckerlöse Harnruhr." But Cloetta [1856], Vohl [1858], and Neukomm [1860], all observed an inosituria accompanying cases of diabetes insipidus, to a greater or less degree. For a time, the fact was expected to throw much light on the etiology of the disease, but it did not do so, and for the following fifty years many workers were trying to associate it, either with diabetes insipidus, diabetes mellitus, or simple polyuria. It was soon found that by no means all cases of diabetes insipidus were also inosituric [Ebstein, 1873; Bürger, 1873], while inosituria was found by Neukomm [1860], Gallois [1864], Mosler [1868], Przibram [1871] and Leva [1891] to be sometimes associated with diabetes mellitus. Külz, however [1875, 1876], made the observation that inositol was excreted to a marked extent in the polyuria caused by an excessive drinking of beer by two German students. Since wine and beer contain inositol this experiment was not conclusive, but he also discovered that the injection of physiological salt solution into rabbits caused an inosituria, as also did the ingestion of large amounts of water in man. From these experiments, there resulted the idea that inosituria was specially to be associated with polyuria, and only appeared in the two types of diabetes when these were complicated by an excessive water-excretion. This view was put forward by Mayer [1907] and Starkenstein [19099] and it was greatly stressed by the latter as it fitted in with his general theory that the inositol of the tissues entered the body in the form of phytin, and possessed no physiological function. In polyuria, it was just being washed out. Meillère [1906] obtained an inosituria by puncture of the fourth ventricle and stated that the inositol reached its 
maximum two hours before the glucose, though he gave no figures in his paper.

There can be no doubt at the present time that inosituria is associated with polyuria of whatever origin, and that its connection with the two forms of diabetes is accidental. If, therefore, a number of rats could be made to undergo artificial polyuria, while at the same time living on a pure diet, from which all inositol was excluded, good evidence would be available on the question of synthesis by the animal body. For an inosituria would accompany the polyuria, and, since no inositol was entering their bodies in their food, it would become clear whether or not they could synthesise it. If after some time the excretion of inositol diminished and ceased although the polyuria still continued, we should have a direct proof that the body was incapable of effecting its synthesis. If, on the other hand, the excretion of inositol was kept up indefinitely in spite of the supplies being cut off, then we should have to conclude that it was being synthesised. The description of such an experiment occupies the main part of this paper.

First, however, we shall describe some experiments with pure diet only.

\section{EXPERIMENTS WITH RATS ON A PURE DIET.}

Quite apart from the effects of a prolonged polyuria, the result of cutting off all cyclose from the diet appeared likely to throw some light on the question of synthesis. Accordingly a number of white rats were placed on a "basal diet" and kept for a long period, one or two being from time to time removed and their inositol-content estimated, as described in the previous paper [1923,1]. The diet was that in general use in the Cambridge Laboratory; it consisted of pure caseinogen, sucrose, and palm-kernel oil as fat, with the addition of a minute quantity of marmite extract and orange juice. The marmite was worked up for inositol, and traces were found in it. Since, however, only three drops were given to each rat every day and free inositol in the food is broken down by intestinal bacteria, this factor would not be expected to influence the results greatly. The figures obtained in this way are given in Table I.

\section{Table I.}

\begin{tabular}{|c|c|c|c|c|c|c|}
\hline \multirow[b]{2}{*}{$\begin{array}{l}\text { Date when } \\
\text { rat was killed }\end{array}$} & \multirow[b]{2}{*}{$\begin{array}{c}\text { Rat } \\
\text { number }\end{array}$} & \multicolumn{2}{|c|}{ Weights } & \multicolumn{3}{|c|}{ Inositol found } \\
\hline & & $\begin{array}{l}\text { Original } \\
\text { weight }\end{array}$ & $\begin{array}{c}\text { Total } \\
\text { tissues }\end{array}$ & $\begin{array}{l}\text { Total mg. } \\
\text { per rat }\end{array}$ & $\begin{array}{c}\text { mg. } \% \\
\text { orig. weight }\end{array}$ & $\begin{array}{c}\text { mg. } \% \\
\text { total tissues }\end{array}$ \\
\hline 23 Oct. 1923 & TRB & $76 \cdot 0$ & $61 \cdot 40$ & $8 \cdot 67$ & $11 \cdot 41$ & $14 \cdot 1$ \\
\hline 31 Oct. 1923 & TRE & $\begin{array}{l}70 \cdot 0 \\
96 \cdot 0\end{array}$ & $\begin{array}{l}46 \cdot 5 \\
64 \cdot 0\end{array}$ & $\begin{array}{l}6 \cdot 34 \\
4 \cdot 97\end{array}$ & $\begin{array}{l}9.06 \\
5.17\end{array}$ & $\begin{array}{r}13 \cdot 63 \\
7.76\end{array}$ \\
\hline 17 Nov. 1923 & TRJ & $110 \cdot 0$ & $70 \cdot 70$ & $21 \cdot 15$ & $19 \cdot 23$ & 9.91 \\
\hline 17 Mar. 1924 & TRO & 247.0 & $132 \cdot 0$ & 14.96 & $6 \cdot 06$ & $11 \cdot 33$ \\
\hline 12 May 1924 & TRP & $268 \cdot 0$ & $153 \cdot 0$ & $16 \cdot 15$ & $6 \cdot 03$ & $10 \cdot 55$ \\
\hline
\end{tabular}

The normal limits of variation for the inositol-content of rats are between 7 and $14 \mathrm{mg}$. \% calculated with reference to the original body weight, and the above table shows that over a period of eight months the inositol-content of rats kept on an inositol-free diet varies only within those limits. In all cases 
the whole body of the rat was included in the estimation, and all that was rejected was the skin and the intestinal contents. The "original weight," therefore, refers to the weight of the animal before death, and the term "total tissues" refers to the weight of the material before extraction with acetone. Death was in all cases brought about by chloroform. These conditions were those under which all the experiments in this paper were carried out.

These experiments seem to point to the view that the body can synthesise inositol, always assuming, of course, that inositol undergoes normally a breakdown in the body. It is true that, as will appear later, there is a good deal of combined inositol present in the body, but nevertheless the fact that rats on an inositol-free diet show no diminution after eight months, in the amount directly estimable in their bodies, can surely not be without significance.

\section{EXPERIMENTS ON RATS WITH ARTIFICIALLY INDUCED POLYURIA.}

\section{Methods.}

As a means of producing a continuous polyuria, recourse was had to a very salt diet. Injection of salt solution and other diuretics was impossible in an experiment planned, as this was, to last months; something that could be taken by the mouth was necessary, and the least unphysiological substance that could be thought of was sodium chloride. It was increased gradually and finally kept at a concentration of $17 \%$ in the food. This quantity did not seem to hurt the animals at all, and certainly succeeded in raising and maintaining a vigorous polyuria, as will be seen later.

The bodies of the rats were treated in the manner described in the last paper for the estimation of inositol, and no modifications were found to be necessary for them. The estimation of inositol in the urine was, however, a more difficult matter and one or two important modifications had to be introduced. In the first place, the earlier workers seem to have taken no precautions to keep the urine of their animals sterile, and in view of the rapidity with which bacteria break down the cycloses, this is a distinct error. B. coli, according to Graham-Smith [1924], is common in urine, especially that of rats, and inositol is broken down readily by it [Meillère, 1907; Starkenstein, 1909, 1911]. Consequently, it was decided to collect the urine in an antiseptic, and chlorine water was chosen, firstly, because it is very toxic to $B$. coli, and secondly, because it passes off when the urine is evaporated down. Some preliminary experiments were made to determine whether it had real protective power. A culture of $B$. coli was sown into one flask containing 25 cc. of rat's urine, and $0.05 \mathrm{~g}$. inositol added. A similar flask was prepared but with the addition of $5 \mathrm{cc}$. of chlorine water. From the first $0.038 \mathrm{~g}$. was recovered, and from the second $0.048 \mathrm{~g}$. Accordingly in all subsequent experiments 10 cc. of chlorine water were added to the vessel in which the urine was collected.

The second modification was concerned with the removal of the inorganic 
salts of the urine before the precipitation with basic lead acetate. Mayer [1907], Anderson [1916] and Greenwald [1917] all used neutral and basic lead acetate precipitations direct on the urine, but they admitted that their method was only approximate. Inorganic salts are known to hinder the precipitation of cycloses by the basic lead salt [Momose, 1916], and these were removed in Starkenstein's method [1909] by a series of precipitations with barium and silver nitrates, sodium phosphate, etc. In order to avoid this, the urine was evaporated down to about $500 \mathrm{cc}$. and plaster of Paris added. The mass does not set hard but forms a dry powder which can easily be extracted with dilute acetone as described for tissues in the first paper of this series. This yielded satisfactory results, $0 \cdot 24$ and $0.228 \mathrm{~g}$. being recovered from $0.25 \mathrm{~g}$. added to $200 \mathrm{cc}$. of urine in two experiments and was greatly superior to Starkenstein's method $(0 \cdot 120,0 \cdot 103,0 \cdot 164 \mathrm{~g}$. recovered).

The rats were confined in cages large enough to hold six animals comfortably. Each cage was furnished with a wire bottom and four tunnels leading out of it at the sides. Underneath the cages were funnels which collected the urine into thick glass vessels. Two of the tunnels led to food while two led to water. A continual drip of water was arranged, so that the drinking-troughs were always full and the animals were never thirsty. By this means the polyuria was kept up continuously.

\section{Experiments.}

Two preliminary experiments were first performed. In order to try to confirm the work of Külz [1876] one of the workers in the laboratory consented to drink a large quantity of water. He ingested between 2.30 and 6.0 p.m. a little over seven litres of water, and excreted between 3.27 and 7.28 p.m. $4210 \mathrm{cc}$. of urine. From this amount, it was possible to isolate $0.45 \mathrm{~g}$. of inositol. Next, 15 rats were made to excrete a considerable amount of urine by giving them $5 \%$ of salt in their diet, and their urine was worked up for inositol. The results were eminently satisfactory. Not only did a marked diuresis appear, but inositol was also present, as is seen from Table II.

\begin{tabular}{|c|c|c|c|}
\hline & $\begin{array}{l}\text { cc. urine per } \\
\text { rat per day }\end{array}$ & $\begin{array}{l}\text { Total mg. } \\
\text { inositol excreted }\end{array}$ & $\begin{array}{l}\text { mg. inositol per } \\
\text { day per rat }\end{array}$ \\
\hline Normal (3 rats) & $15 \cdot 5$ & 0.0 & 0.0 \\
\hline Polyuria (15 rats) & & & \\
\hline First day & $38 \cdot 0$ & $10 \cdot 07$ & 0.72 \\
\hline Second day & $66 \cdot 67$ & 12.95 & $0 \cdot 86$ \\
\hline Third day & $93 \cdot 33$ & $7 \cdot 61$ & 0.51 \\
\hline Fourth day & $60 \cdot 66$ & $11 \cdot 80$ & 0.79 \\
\hline
\end{tabular}

From these results it was obvious that a polyuria could be induced in rats, that it could be accompanied by an inosituria and that the inositol was excreted in easily measurable amount. Nothing remained but to see how long this could continue on a pure diet.

Eighteen large rats, weighing in toto a little over seven kilos., were there- 
fore confined in four cages of the type described, and placed on a pure diet for three days to accustom them to it. Then sodium chloride was added to their food in gradually increasing quantities, rising to $15 \%$. Table III and Fig. 1 show the results which were obtained.

Table III.

Total amount of urine cc.

270

510

615

810

1040

1370

1840

1700

845

2100

2030

2120

2280

2110

2240

2360

1720

2270

1800

2020

2430

2260

2220 cc. urine
per rat

$\%$ salt

in diet

5

9
12

15

15

15

15

15

15

15

15

15

15

15

15

15

15

15

15

15 per rat
per day

15.5

$28 \cdot 3$

$34 \cdot 2$

45. 0

$\mathbf{5 7 \cdot 7}$

$76 \cdot 1$

$102 \cdot 2$

$\mathbf{9 4} \cdot 4$

46.9

$116 \cdot 6$

$112 \cdot 8$

$117 \cdot 8$

$126 \cdot 7$

$117 \cdot 2$

124.5

$131 \cdot 1$

95.5

126. 1

$100 \cdot 0$

112.2

135.0

$125 \cdot 5$

123.3

Total mg. inositol excreted per rat

Calculated by interpolation

\begin{tabular}{|c|c|c|}
\hline Per day & $\begin{array}{l}\text { Per day } \\
\text { per rat }\end{array}$ & $\begin{array}{c}\% \\
\text { of urine }\end{array}$ \\
\hline $5 \cdot 15$ & $0 \cdot 286$ & $1 \cdot 845$ \\
\hline $14 \cdot 21$ & 0.789 & $2 \cdot 785$ \\
\hline $22 \cdot 49$ & $1 \cdot 249$ & $3 \cdot 655$ \\
\hline $9 \cdot 86$ & 0.547 & $1 \cdot 215$ \\
\hline $11 \cdot 00$ & $0 \cdot 611$ & 1.058 \\
\hline$[14.50]$ & {$[0 \cdot 805]$} & - \\
\hline $18 \cdot 67$ & 1.035 & $1 \cdot 013$ \\
\hline$[14 \cdot 50]$ & {$[0 \cdot 805]$} & - \\
\hline $11 \cdot 17$ & 0.620 & $1 \cdot 320$ \\
\hline$[17 \cdot 00]$ & {$[0.944]$} & - \\
\hline 22.93 & $1 \cdot 274$ & $1 \cdot 130$ \\
\hline 30.59 & $1 \cdot 699$ & $1 \cdot 445$ \\
\hline $17 \cdot 39$ & 0.965 & $0 \cdot 761$ \\
\hline$[13.00]$ & {$[0 \cdot 722]$} & - \\
\hline $9 \cdot 46^{\circ}$ & 0.504 & $0 \cdot 405$ \\
\hline $23 \cdot 66$ & $1 \cdot 314$ & 1.002 \\
\hline 50.58 & $2 \cdot 809$ & 2.941 \\
\hline 36.98 & $2 \cdot 054$ & $1 \cdot 630$ \\
\hline 30.93 & $1 \cdot 718$ & $1 \cdot 718$ \\
\hline $22 \cdot 37$ & $1 \cdot 243$ & $1 \cdot 111$ \\
\hline $78 \cdot 66$ & $4 \cdot 369$ & $3 \cdot 237$ \\
\hline $47 \cdot 90$ & $2 \cdot 661$ & $2 \cdot 120$ \\
\hline $39 \cdot 42$ & $2 \cdot 190$ & $1 \cdot 776$ \\
\hline
\end{tabular}

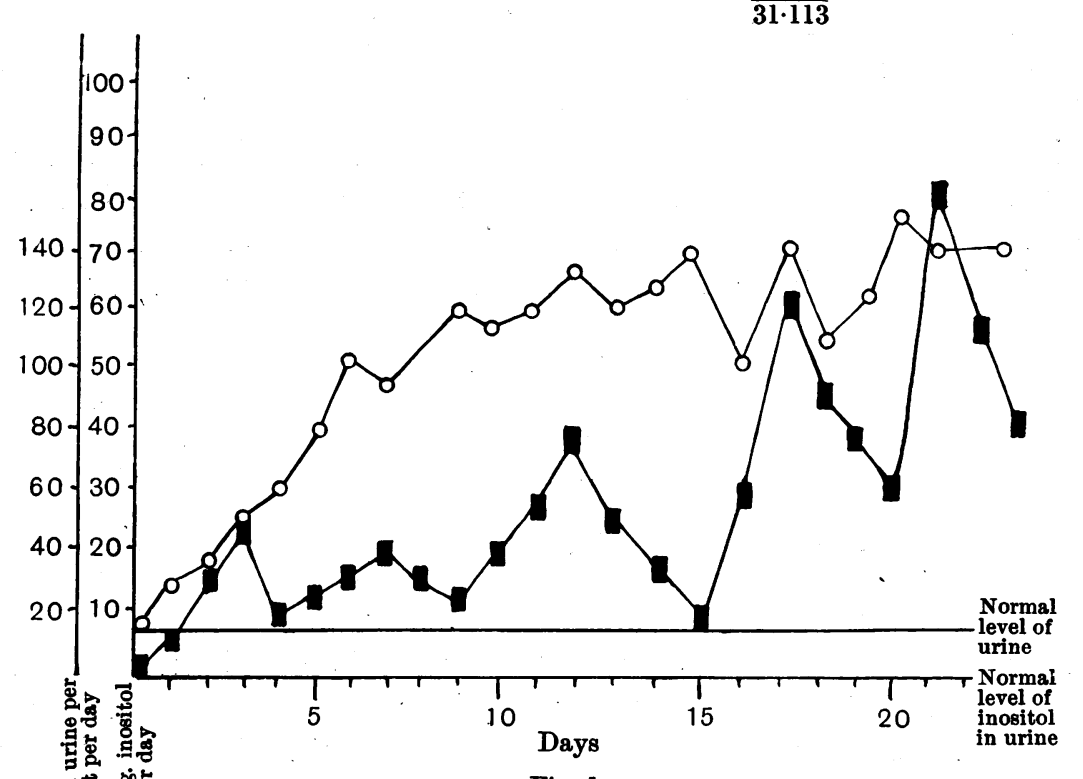

Fig. 1.

$\mathrm{O}=$ urine in ccs.

=Inositol in mgms.

The size of the black squares indicates the possible error. 
It is clear, therefore, that over a period of 23 days' polyuria, during which the excretion of urine was raised to as much as nine times the normal, inositol was continuously excreted. But the most interesting thing that appears from Fig. 1 is the rhythm with which this was done. In peaks of gradually ascending height the concentration of cyclose in the urine rises until it is about eight times the ordinary excretion. On the twenty-third day the experiment was stopped and most of the animals killed for the estimation of the inositol that they contained. Would the difference in their body-content account for the $31 \mathrm{mg}$. which they had each excreted, or would a synthesis have to be postulated? The results are given in Table IV.

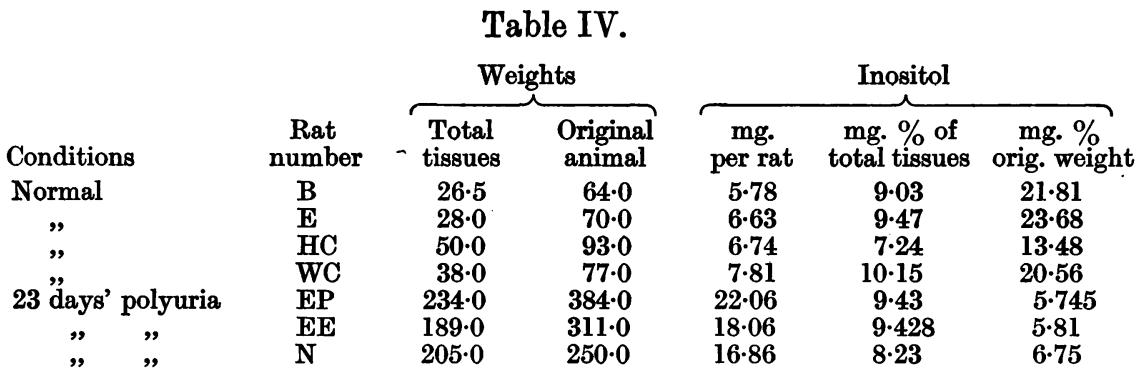

It is obvious that there has been no change in the free inositol estimable directly, before and after the polyuria. It does not even vary greatly within the normal limits of change, but remains almost constant at $9 \mathrm{mg}$. \%. However, there remains still the question of "inositogen." The first worker to suggest the presence in the tissues of a precursor of inositol, capable of being split down to inositol by tissue enzymes was Rosenberger [1908, 1909, 1910]. His first experiments were not very definite, for he compared the amount of inositol present in beef which had been exposed for sale with that present in fresh rabbit muscle, having ascertained for neither the limits of normal variation. However, in later work, he suspended minced rat muscle in salt solution and autolysed it for three days, after which he was able to isolate very much more inositol than he could from the fresh muscle. Unfortunately, he gave no figures, and his method, which involved boiling with concentrated $\mathrm{HNO}_{3}$ and baryta, received much just criticism [Starkenstein, 1908]. He ventured no distinct view as to what the precursor might be except to suggest that it might be the "tyrophenositol" of Müller [1907] and Danileffski [1880]. Starkenstein [1909] could not succeed in obtaining the differences that Rosenberger had reported, and threw doubt on the existence of an inositogen, although he thought that if it existed it might be phytin or a phytin-like compound, absorbed from the intestine. The presence of a phytase in certain tissues, reported by McCollum and Hart [1908] seemed to favour this belief. The present writer, moreover, was able to isolate in 1923 more inositol from a rabbit which had been dead two days than from one freshly killed. Accordingly, although polyuria continued for 23 days seemed to have no effect upon the 
free inositol of the rat, it was possible that it had decreased the store of combined inositol, kept the amount of free substance at a constant level, and rendered the experiment no proof of synthesis. To test this point, autolysis experiments were carried out and are shown in Table V.

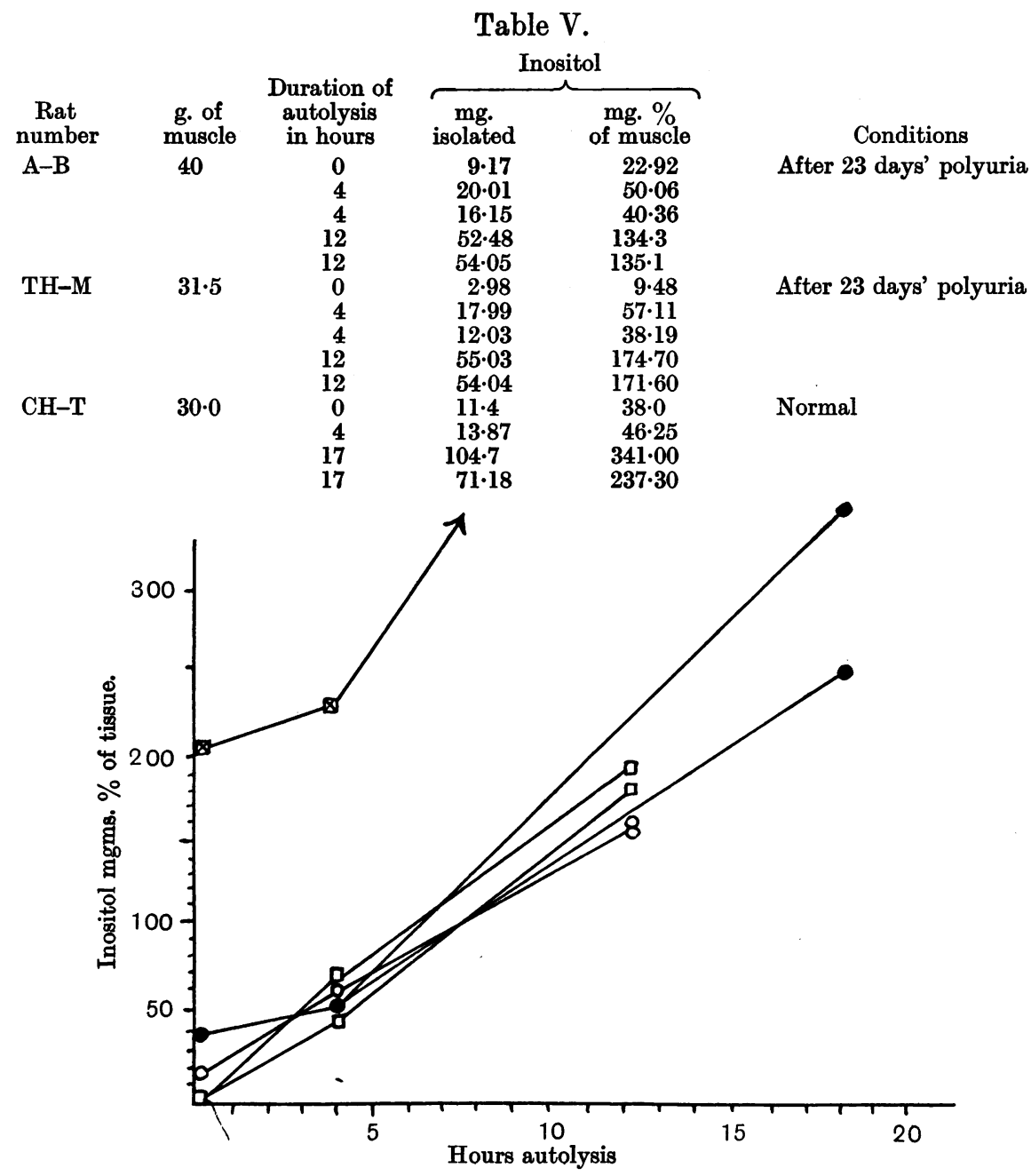

Fig. 2.

- Normal. $凶 70$ days' polyuria.

$$
\bigcirc\{23 \text { days' polyuria. }
$$

Two rats, which had been under similar conditions, were taken, and enough of their skeletal musculature minced to provide five portions of about $30 \mathrm{~g}$. each. One of these was estimated directly, and four were suspended in $250 \mathrm{cc}$. of phosphate buffer solution [Cole, 1919] at a $p_{\mathbf{H}}$ of 7.00. To each of these $10 \mathrm{cc}$. of toluene were added and two of them allowed to autolyse for 4 hours, while two were left for 12 hours, all at $37^{\circ}$. 
These figures may be considered strong evidence in favour of the existence of inositol in the combined state capable of being liberated on autolysis. It must, however, be remembered that in a mixture of substances such as autolysis produces, there is always the possibility that unknown bodies may be estimated as inositol. But the figures also showed that the experiment just described was not quite conclusive proof that a synthesis of inositol had been going on to supply the excreted substance. For although the figures for total body-content had remained the same there was a slight diminution in the amount of inositol capable of being liberated by 12 hours' autolysis, and this was still the case even when the longer autolysis in the control was allowed for (see Fig. 2). Moreover, the gradually increasing rhythmic output of inositol shown in Fig. 1 led naturally to the question of how long this would continue. Accordingly, it was decided to repeat the whole experiment, employing just the same conditions, and a very much longer time.

Since this second experiment was planned to cover several months, it was not possible to estimate the inositol in each day's urine; instead, the urine was kept at $-2^{\circ}$ for five days, and then the massed amounts estimated in five-day periods. The salt content of the food was held at $17 \%$ in lieu of $15 \%$, and the rats were allowed a week to get used to their pure unsalted diet, but otherwise there was no change in the conditions. From time to time tests were made on the urine for glucose and albumin; but in no case was glucose found (Benedict) while albumin only appeared about the 80th day (sulphosalicylic acid). Creatine was found to be present [cf. Fowler and Hawk, 1910].

Table VI.

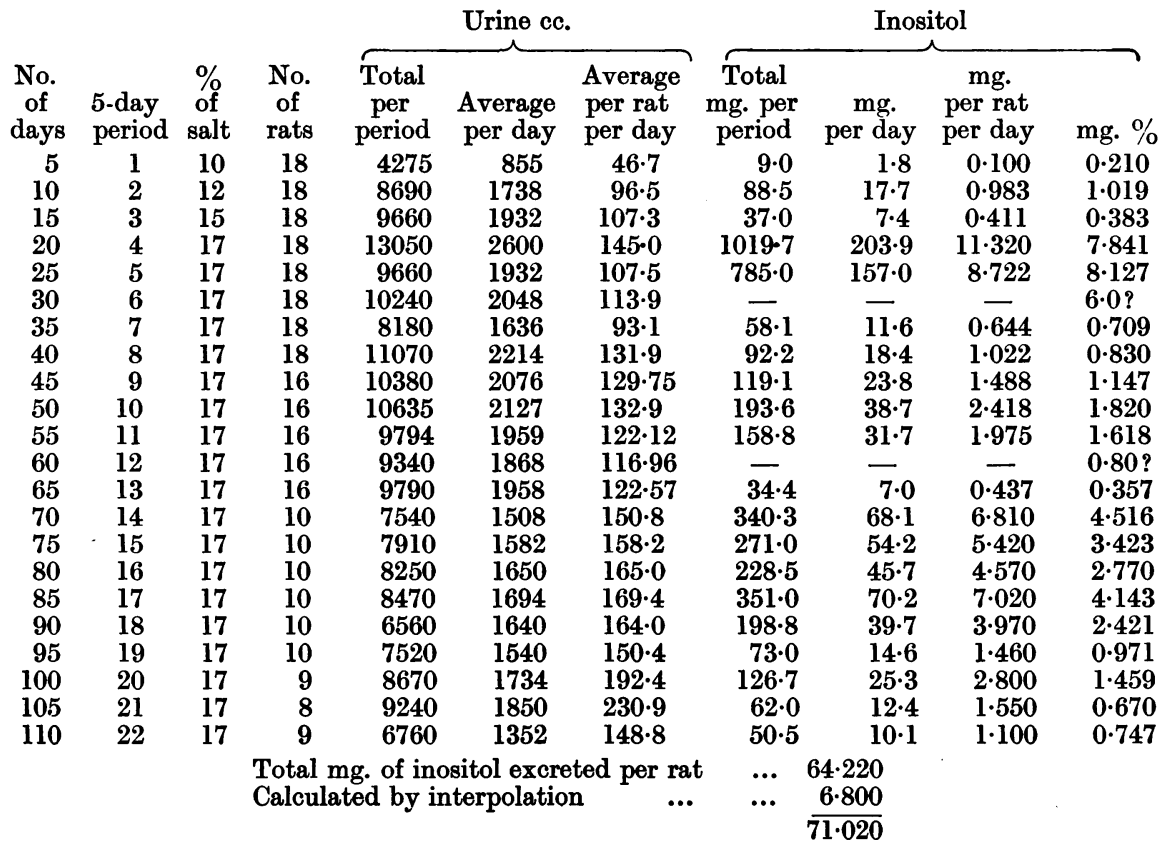


From Table VI and from the graphic representation of the same figures (Fig. 3), there remains no doubt that over a period of 110 days of artificially induced polyuria, inositol is constantly excreted. The total amount actually excreted by one rat during the whole period amounts to $71 \mathrm{mg}$., and in the absence of any inositol from the diet, the evidence for synthesis is complete. The second experiment is in good correspondence with the first, because in both cases the maximum excretion occurs about the third week. In the first case it was actually in the 21st day, in the second case about the 19th

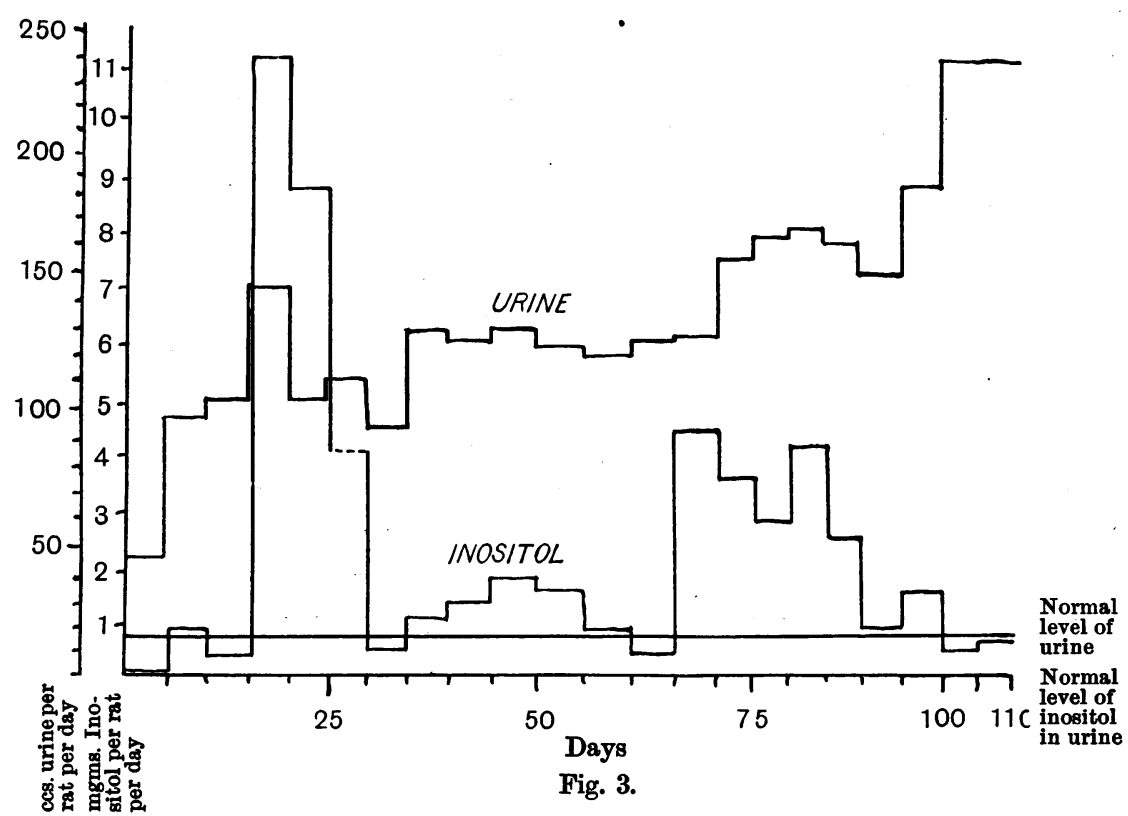

day, at any rate, between the 15th and the 20th days. The first experiment ended shortly after, but in the second one, a fall to a constant level takes place, and the excretion continues steadily for some time at a level of from $1.5-2.5 \mathrm{mg}$. per rat per day. Thereafter, other changes occur. The number of rats is reduced to 10 at the 70th day, to 9 at the 100th day, and lastly to 8 . Profound histological changes take place in the kidneys, and then the output of cyclose rises.

In order to make sure that the continuing output of inositol was not due to a mere depletion of the inositol liberated by overnight autolysis, similar autolysis experiments to those described above were carried out on the four rats killed on the 70th day. The results are given in Table VII.

These figures, when compared with those in Table $\mathrm{V}$, show very large increase in the amount of free inositol as well as in that of the inositol liberated by overnight autolysis. On the other hand, the amount of inositol liberated by 4 hours' autolysis is relatively lower than the normal. The exact interpretation of these figures can hardly be attempted till we know more of the 
ordinary course of autolysis in muscle as regards the cyclose group, yet at the same time they do show that whatever else has happened, there has been no decrease in the inositol of the body after prolonged inosituria on pure diet. Perhaps an over-compensation has taken place.

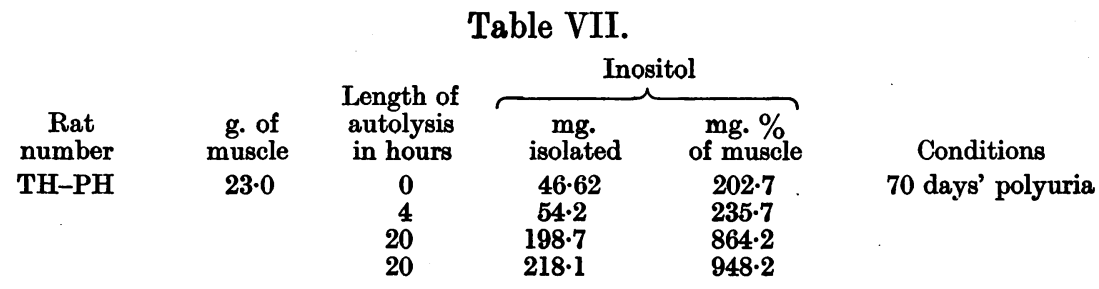

How had the kidneys behaved under this strain? At the 45th day two rats died. They were very puffed up, their abdominal distention being due not to liquid but to gas in their intestines. This must probably not be considered as having anything to do with the salt diet, for death with abdominal distention is comparatively frequent when rats are fed for some time on a pure diet. Their kidneys were excised and placed in Carnoy's fluid to await histological examination. Then on the 70th day four further rats were killed, and from two of them kidney sections were made.

The sections reveal a progressive degeneration. At 45 days there is some breakdown of the tubule cells, though this is more marked in some areas than others. In other places there is evident a clumping together of nuclei, though on the whole the tubules are of normal shape. But the most remarkable point is the great shrinking of the glomeruli, a phenomenon not due to the method of preparation, for the controls did not show it. Instead of filling up the whole glomerular space, the glomerulus only fills half of it or so.

After 25 more days' polyuria, the degeneration is much more marked, especially as regards nuclei. There is hardly a single nucleus left, and the tubules have largely lost their shape. Masses of pigment are seen in a few places and in most of the glomeruli the nuclei are entirely absent. The whole picture is one of enormous nuclear degeneration, together with general breakdown of cells.

These appearances coincide well with the few data that we have as to the histological appearances of kidneys in human beings who died from diabetes insipidus or other forms of excessive polyuria. The only available information on this point seems to be that given by W. Roberts [1865]. In six post-mortems of diabetes insipidus cases, three kidneys were much diminished in size, and three were very large and flaccid. But histologically, the same appearances were present in each, shrunken glomeruli, degenerating tubules, and in the worst cases, disappearance of the characteristics of kidney tissue. Degeneration, then, seems to accompany excessive and long-continued polyuria, and this fact explains why the constancy in inositol excretion seen in the 6th to the 13th periods is not maintained. Probably after a certain time, the 
threshold for most substances is altered by the degeneration, and inositol begins to leak through. The constant level of inosituria can no longer be maintained.

\section{Discussion.}

Two lines of evidence point to the conviction that inositol is capable of being synthesised by the animal body. We have seen that there is no change in the inositol content of rats after eight months on an inositol-free diet, and we have seen also that on the same diet, a vigorous inosituria causes no diminution of the body-cyclose. These are supported by a third, the behaviour of inositol in the developing egg. It was shown [Needham, 1923, 2] that the inositol content of the unincubated hen's egg is about $6 \mathrm{mg} . \%$, while at the end of development it has risen to $60 \mathrm{mg}$. \%. Now if all this inositol had existed in the form of a phytin-like compound at the beginning, and even if it had been in the form of a monophosphate, about double the water-soluble phosphorus present at the beginning would have been needed, using the figures of Plimmer and Scott [1909]. Accordingly, unless some compound other than a phosphorus one is postulated as the precursor of inositol, the conclusion is that a synthesis of inositol has taken place. Though this is an indirect consideration, nevertheless it reinforces the other lines of evidence.

Four modes of reaction might have occurred in the polyuria experiments:

1. Excretion ceases after a time. Body-content lowered.

2. $", \quad, \quad$ raised or normal.

3. Excretion continues indefinitely. Body-content lowered.

4. " " " ",$\quad$ raised or normal.

Both alternatives 1 and 2 would imply that the body had no power of synthesising the substance. In No. 1 the cyclose would have simply been washed out of the body by the polyuria, in No. 2 the body would have retained a certain amount, possibly as a necessary constituent of the internal environment of the cells. In both alternatives 3 and 4, however, synthesis would have taken place. Alternative 3 would indicate that no great quantity of cyclose was necessary for the body and that only enough was being synthesised to excrete. The fourth alternative, however, would seem to show that the body does indeed require it and can produce sufficient, not only for the demands of the inosituric condition, but also for its own uses.

The fourth alternative was the one found. This result has some bearing on the views which have been held concerning the general significance of the cyclose group. The only worker to hold a general position on the matter was Starkenstein [1909], who considered that inositol possessed "no special physiological significance" and subserved no important function in the body. It entered, he thought, in the form of phytin obtained from plants, and when the phosphorus was split off from it in the tissues, simply remained there as an inert constituent. Thence it was merely washed out in polyuric states. If, however, this was the case, the first alternative would have been expected. 
The inositol stored by accident, as it were, in the rats' tissues would have been washed out and after a time the excretion would have stopped when the animal had become cyclose-free. In actual fact, the contrast to this was marked. A real synthesis undoubtedly took place, and Starkenstein's theory becomes accordingly difficult to hold. The fact that synthesis does take place is, of course, no proof that inositol has any metabolic significance, for it might owe its existence to the chance presence of its precursors. But substances which possess physiological significance are surely more likely to be synthesised by the animal body than substances which have no part to play in metabolism.

\section{SUMmaRY.}

1. There is no change in the amount of free inositol contained in the tissues of the rat after eight months on an inositol-free diet.

2. Polyuria and inosituria artificially induced in rats by feeding them on a salt diet over a period of 110 days, caused a lasting and vigorous excretion of inositol, without any diminution in their body-content, although the diet was inositol-free.

3. The animal body appears to possess the power of synthesising inositol.

The author wishes firstly to express his sense of indebtedness to Professor F. G. Hopkins for his continual inspiration and encouragement. He desires also to thank Mr J. B. S. Haldane and Mr John Freeman; the former for his help as an experimental subject and the latter for carrying out the histological work. Finally he would thank Dr Graham-Smith for his advice concerning bacteria in urine.

\section{REFERENCES.}

Anderson (1916). J. Biol. Chem. 25, 401.

Bürger (1873). Deutsch. Arch. klin. Med. 11, 343.

Cloetta (1856). Liebig's Annalen, 99, 302.

Cole (1919). Practical Physiological Chemistry (Heffer and Sons).

Danileffski (1880). Ber. deutsch. Chem. Ges. 13, 2132.

Ebstein (1873). Deutsch. Arch. klin. Med. 11, 352.

Fowler and Hawk (1910). J. Exp. Med. 12, 388.

Hopkins (1923). Private Communication to the author.

Gallois (1864). Thesis, Paris.

Graham-Smith (1924). Private Communication to the author.

Greenwald (1917). J. Biol. Chem. 31, 1.

Klein (1909). Dissert. (Giessen).

Külz (1875). Med. Centr. Maly, 131; (1876) 124 and 45.

- (1876). Sitzber. Ges. Naturwiss. Marburg, 4.

Leva (1891). Deutsch. Arch. klin. Med. 48, 173.

Mayer (1907). Biochem. Z. 2, 393.

McCollum and Hart (1908). J. Biol. Chem. 4, 497.

Meillère (1906). Compt. Rend. Soc. Biol. (2), 159.

- (1907). Compt. Rend. Soc. Biol. 1096.

Momose (1916). Biochem. J. 10, 120.

Mosler (1868). Virchow's Arch. 43, 229.

Müller (1907). Sitz. Naturforschergesel. Rostock, 19 
Needham $(1923,1)$ Biochem. J. 17, 422, 431.

- (1923, 2). J. Physiol. 57, Proc. Ixxx.

Neukomm (1860). Dissert. Zürich.

Offergeld (1906). Z. Gebürtsh. Gynäkol. 58, 189.

Plimmer and Scott (1909). J. Physiol. 38, 247.

Przibram (1871). Vierteljahrsch. prakt. Heilk. 112, 1.

Roberts (1865). Urinary and Renal Diseases.

Rosenberger (1908). Z. physiol. Chem. 56, 373; 57, 464.

— (1909). Z. physiol. Chem. 58, 369. (1910). Z. physiol. Chem. 64, 341.

Starkenstein (1908). Z. physiol. Chem. 58, 162. (1909). Z. exp. Path. Therap. 5, 378.

(1911). Biochem. Z. 30, 56.

Vohl (1858). Arch. Physiol. Heilk. 17, 410. 